\title{
Magnetic nanoparticle of $\mathrm{Fe}_{3} \mathrm{O}_{4}$ and 5-bromotetrandrin interact synergistically to induce apoptosis by daunorubicin in leukemia cells
}

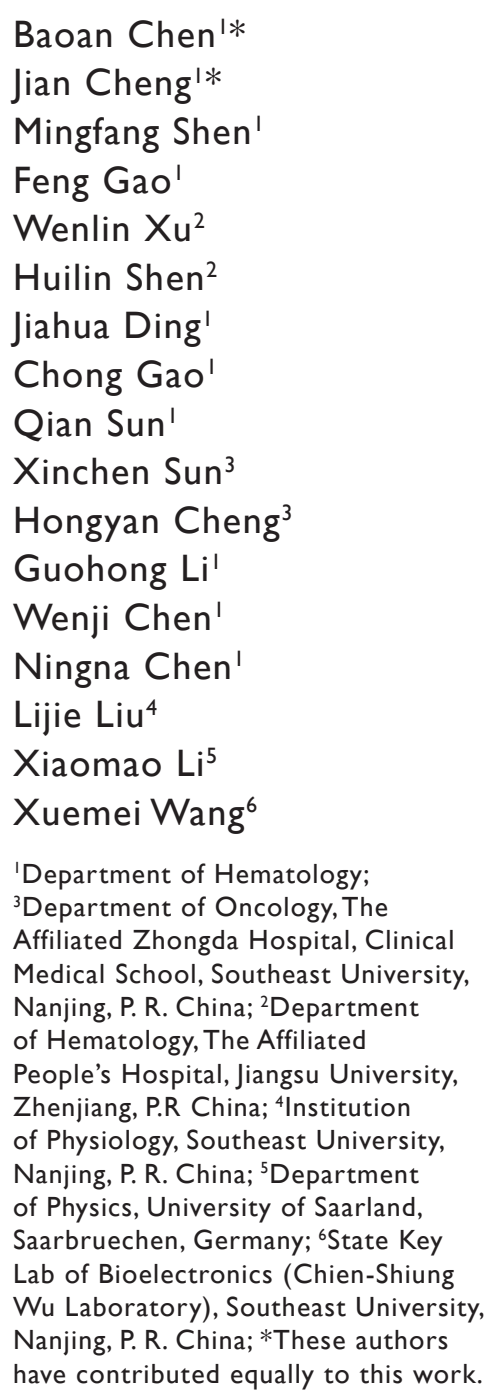

Correspondence: Mingfang Shen Department of Hematology, The Affiliated Zhongda Hospital, Clinical Medical School, Southeast University, Nanjing, 210009

P.R. China

Tel +86 25 | 3776605367

Fax +8625832 720II

Email xiaofang821103@।63.com

\begin{abstract}
Apoptosis is a common pathway that finally mediated the killing functions of anticancer drugs, which is an important cause of multidrug resistance (MDR). The aim of this study was to investigate the potential benefit of combination therapy with magnetic nanoparticle of $\mathrm{Fe}_{3} \mathrm{O}_{4}\left(\mathrm{MNP}\left(\mathrm{Fe}_{3} \mathrm{O}_{4}\right)\right)$ and 5-bromotetrandrin (BrTet). Analysis of the apoptosis percentage showed that combination of daunorubicin (DNR) with either $\mathrm{MNP}\left(\mathrm{Fe}_{3} \mathrm{O}_{4}\right)$ or BrTet exerted a potent cytotoxic effect on $\mathrm{K} 562 / \mathrm{A} 02$ cells, while $\mathrm{MNP}\left(\mathrm{Fe}_{3} \mathrm{O}_{4}\right)$ and BrTet cotreatment can synergistically enhance DNR-induced apoptosis. Importantly, we confirmed that the distinct synergism effect of that composite on reverse multidrug resistance may owe to the regulation of various proliferative and antiapoptotic gene products, including P53 and caspase-3. Thus our in vitro data strongly suggests a potential clinical application of $\mathrm{MNP}\left(\mathrm{Fe}_{3} \mathrm{O}_{4}\right)$ and $\mathrm{BrTet}$ combination on CML.
\end{abstract}

Keywords: K562/A02 leukemic cells, multidrug resistance, magnetic nanoparticle of $\mathrm{Fe}_{3} \mathrm{O}_{4}$, 5-bromotetrandrine, apoptosis, P53, caspase-3

\section{Introduction}

The primary cause of treatment failures in leukemia is the emergence of multidrug resistance (MDR). ${ }^{1,2}$ Most chemotherapy agents are used in the treatment of hematologic malignancies cells by inducing apoptosis; the resistance of leukemic cells to chemotherapy-induced apoptosis remains the most significant problem in the treatment of leukemia., ${ }^{3,4}$ To reverse the resistance mechanism and reduce side effects during chemotherapy, a promising approach is to combine a conventional chemotherapy with new strategies inducing leukemia cell apoptosis. The possible solutions may include using drug delivery systems to enhance the related drug delivery efficiency to cancer cells and chemosensitizers to inhibit ATP-binding cassette (ABC) transporters. ${ }^{5}$ In order to achieve this goal, we chose the application of magnetic nanoparticle of $\mathrm{Fe}_{3} \mathrm{O}_{4}\left(\mathrm{MNP}\left(\mathrm{Fe}_{3} \mathrm{O}_{4}\right)\right)$ and 5-bromotetrandrin (BrTet) to sensitize MDR cells in acute leukemia.

Traditional strategies towards the tissue-specific drug delivery utilize cytotoxic drugs attached to targeting moieties. ${ }^{6}$ Recently, many polymer nanospheres and nanoparticles have been introduced as drug delivery systems to enhance the related drug delivery efficiency to cancer cells based on the ability to target specific locations in the body. ${ }^{7}$ Perhaps the most promising materials related to diagnosis and treatment of cancer are magnetic nanoparticles. Their magnetic properties enable these particles to be used in numerous applications ${ }^{8}$ such as being guided or held in place by means of a magnetic field and heated in a magnetic field to trigger drug release or to produce hyperthermia of tissue. $\mathrm{Fe}_{3} \mathrm{O}_{4}$ magnetic nanoparticles, a kind of biocompatible nanomaterial that is feasible to produce, characterize, and easily functionalize, are 
widely used for targeted-drug carriers with target-orientation and sustained-release properties because of their chemical stability, low toxicity, and superparamagnetic qualities. ${ }^{9}$ Some reports have demonstrated the synergistic effect of $\mathrm{MNP}\left(\mathrm{Fe}_{3} \mathrm{O}_{4}\right)$ with the anticancer drug daunorubicin (DNR) on the drug accumulation of leukemia cells. ${ }^{10}$ The diameter of $\mathrm{MNP}\left(\mathrm{Fe}_{3} \mathrm{O}_{4}\right)$ manufactured by Biological Science College of Southeast University is $20-30 \mathrm{~nm}$, which is appropriate for reversal of MDR. ${ }^{11}$

Tetrandrine (Tet), a bisbenzylisoquinoline albaloid isolated from the Chinese herb "Hanfangji" (Stephania tetrandra Radix), holds great promise as a MDR modulator for the treatment of P-glycoprotein (P-gp)-mediated MDR cancers $^{12}$ which have no apparent effect on doxorubicin pharmacokinetics in mice. ${ }^{13}$ Moreover, it is relatively well tolerated in these patients with poor risk acute myeloid leukemia (AML). ${ }^{14}$ 5-Bromotetrandrine (BrTet), a bromized derivative of tetrandrine (Tet), shows more significant MDR reversal activity in vitro and in vivo related to the inhibition of P-gp overexpression and the increase in intracellular accumulation of anticancer drugs. ${ }^{15,16}$

The present studies were undertaken to evaluate the ability of $\mathrm{MNP}\left(\mathrm{Fe}_{3} \mathrm{O}_{4}\right)$ and BrTet to sensitize MDR cells to anticancer agents in vitro and determine their combination effects on apoptosis induced by combining DNR in leukemic cells. Flow cytometry studies demonstrated that $\mathrm{MNP}\left(\mathrm{Fe}_{3} \mathrm{O}_{4}\right)$ and/or BrTet could enhance DNR-induced apoptosis in K562/A02 cells. Moreover, DNA gel electrophoresis revealed that the effects of $\mathrm{MNP}\left(\mathrm{Fe}_{3} \mathrm{O}_{4}\right)$ and BrTet combining with small dose chemotherapeutic agents were different from the effects of large dose chemotherapeutic agents on K562/A02 cells which induced necrosis. Importantly, by measuring the expressions of apoptosis-related gene and proteins, we found a distinct synergistic effect of that composite on reverse MDR may owe to the regulation of various proliferative and antiapoptotic gene products, including P53 and caspase-3, thus demonstrating the potential for using $\mathrm{MNP}\left(\mathrm{Fe}_{3} \mathrm{O}_{4}\right)$ and BrTet as a more sufficient and less toxic anti-MDR method.

\section{Materials and methods Main reagents}

Adriamycin (ADM; Hisun Phamaceutical Co., Zhejiang, China) and DNR (Main Luck Phamaceuticals Inc., Shenzheng, China) stock solution $2 \mathrm{mg} / \mathrm{ml}$ were prepared with $0.01 \mathrm{~mol} / 1$ phosphate buffer saline (PBS) (PH 7.4). BrTet (Kanghong, Chengdou, China) was diluted with 0.01 mol/1 PBS (PH 7.4). $\mathrm{Fe}_{3} \mathrm{O}_{4}$ nanoparticles (State Key Lab of
Bioelectronics, Chien-Shiung Wu Laboratory, Southeast University, Nanjing, China) were well distributed in RPMI 1640 medium (Gibco/BRL, Carlsbad, CA, USA) containing $10 \%(\mathrm{v} / \mathrm{v})$ heat-inactivated new-born calf serum (Sijiqing, Hangzhou, China) by using ultrasound treatment in order to obtain $\mathrm{MNP}\left(\mathrm{Fe}_{3} \mathrm{O}_{4}\right)$ colloidal suspension. DNR conjugated with $\mathrm{MNP}\left(\mathrm{Fe}_{3} \mathrm{O}_{4}\right)$ were prepared by mechanical absorption polymerization at $4{ }^{\circ} \mathrm{C}$ for $48 \mathrm{~h}$ as previously reported. ${ }^{11}$

\section{Cell lines and culture conditions}

Human leukemia cell line K562 and its adriamycin-selected Pgp-overexpressing subline K562/A02 were obtained from the Institute of Hematology, Chinese Academy of Medical Sciences (Tianjin, China). Both cells were cultured in RPMI 1640 medium (Gibco/BRL) containing 10\%(v/v) heat-inactivated new-born calf serum (Sijiqing), $100 \mathrm{U} / \mathrm{ml}$ penicillin and $100 \mu \mathrm{g} / \mathrm{ml}$ streptomycin at $37^{\circ} \mathrm{C}$ in a humidified $5 \% \mathrm{CO}_{2}$ incubator. K562/A02 was cultured in the medium containing $1 \mu \mathrm{g} / \mathrm{ml}$ adriamycin for maintaining MDR phenotype, and maintained in drug-free medium for at least seven days before used.

\section{Flow cytometric apoptosis assay}

The apoptosis rates were measured using flow cytometric assay. ${ }^{17}$ Cell labeling by Annexin-V conjugated to fluorescein isothiocyanate (FITC; Trevigen, Gaithersburg, MD, USA), which binds to phosphatidylserine exposed on the surface membrane of cells undergoing apoptosis. After the $48 \mathrm{~h}$ incubation in the medium containing different drugs at $37{ }^{\circ} \mathrm{C}$, cell suspensions were washed twice with PBS and centrifugation at $1000 \mathrm{r} / \mathrm{min}$ for $5 \mathrm{~min}$. Then the cells were suspended in $500 \mu \mathrm{l}$ of binding buffer (KenGen, Nanjing, China) and $5 \mu \mathrm{l}$ of Annexin V-FITC (KenGen, Nanjing, China), incubated at room temperature for $15 \mathrm{~min}$ in the dark. The samples were measured on a flow cytometry with CellQuest software (Becton Dickinson).

\section{DNA agarose gel electrophoresis}

The typical biochemistry feature of apoptotic was detected by DNA gel electrophoresis. ${ }^{8}$ After treatment with the drugs, we used Apotosis DNA Ladder Detection Kit (KenGen, China) to extract DNA and then analyze DNA by electrophoresis in $1.5 \%$ agarose gels, stained with $0.5 \mathrm{ug} / \mathrm{ml}$ ethidium bromide (Tiangen Biotech, Beijing, China), photographed on an ultraviolet transilluminator. Standard molecular-weight markers (DNA Marker DL2000; Dongsheng, Guangzhou, China) were electrophoresed on each gel. 


\section{Quantitative real-time PCR (QPCR) analysis}

After treatment with drugs, total RNA was isolated using Trizol reagent (Invitrogen Life Technologies, Carlsbad, CA, USA) according to the manufacturer's protocol. One microgram of total RNA was used to generate cDNA using SuperScript ${ }^{\mathrm{TM}}$ II reverse transcriptase (Invitrogen Life Technologies). PCR primers were designed to amplify products within target and control sequences. (Primer sequences: P53(422bp):forward:5'-ACCCAGGTCCAGATGAAG-3'; reverse:5'-CACTCGGATAAGATGCTGA-3'.Caspase3(270bp):forward:5'-GCTATTGTGAGGCGGTTGT3',reverse:5'-TGTTTCCCTGAGGTTTGC-3'.GAPDH(205bp): forward:5'-CGGATTTGGTCGTATTG-3';reverse:5'GAAGATGGTGATGGGATT-3') QPCR was performed by monitoring in real-time the increase in fluorescence of SYBR green I dye (Takara, Shiga, Japan) with Rotor-Gene 3000 (Corbett Research, Sydney, Australia). Each experiment was done in triplicate. The relative gene copy number was calculated by the concentration-CT standard curve method and normalized using the average expression of GAPDH. ${ }^{19}$

\section{Western blot analysis}

After drug treatment, total protein was isolated and subjected to sodium dodecyl sulfate PAGE, and transferred to a polyvinylidene difluoride membrane. The blots were stained with primary antibodies (1:1000-1200) overnight at $4{ }^{\circ} \mathrm{C}$, and then with horseradish peroxidase conjugated goat antirabbit or mouse secondary antibody (1:5000) for $1 \mathrm{~h}$ at room temperature. The signal was detected with an ECL Western Blotting Detection Kit (ZhongShan Co., Beijing, China). After normalization by the corresponding expression of $\beta$-actin, protein expression levels were determined by densitometry scans. ${ }^{19}$

\section{Statistical analysis}

All experiments were repeated at least three times, data were expressed as mean $\pm \mathrm{SD}$ and analyzed with the Statistical Package for Social Science (SPSS Release 11.5; SPSS Inc., Chicago, IL, USA). Differences were evaluated using one-way ANOVA. A P value of $<0.05$ was considered to be statistically significant.

\section{Results}

\section{Enhancement of DNR-induced apoptosis in $\mathrm{K} 562 / \mathrm{A} 02$ cells}

The apoptotic percentage of K562/A02 cells induced by DNR with $\mathrm{MNP}\left(\mathrm{Fe}_{3} \mathrm{O}_{4}\right)(50 \mu \mathrm{M})$ or $\operatorname{BrTet}(0.5 \mu \mathrm{M})$ increased by $15.60 \% \pm 0.76 \%$ and $19.53 \% \pm 0.67 \%$, respectively, compared with DNR alone $(8.30 \% \pm 0.40 \%)$ ( $\mathrm{p}<0.05)$, while co-treatment of DNR with $\mathrm{MNP}\left(\mathrm{Fe}_{3} \mathrm{O}_{4}\right)$ $(50 \mu \mathrm{M})$ and $\operatorname{BrTet}(0.5 \mu \mathrm{M})$ significantly increased Annexin-V staining at $40.20 \% \pm 1.49 \%(\mathrm{p}<0.05)$ (Figure 1$)$.

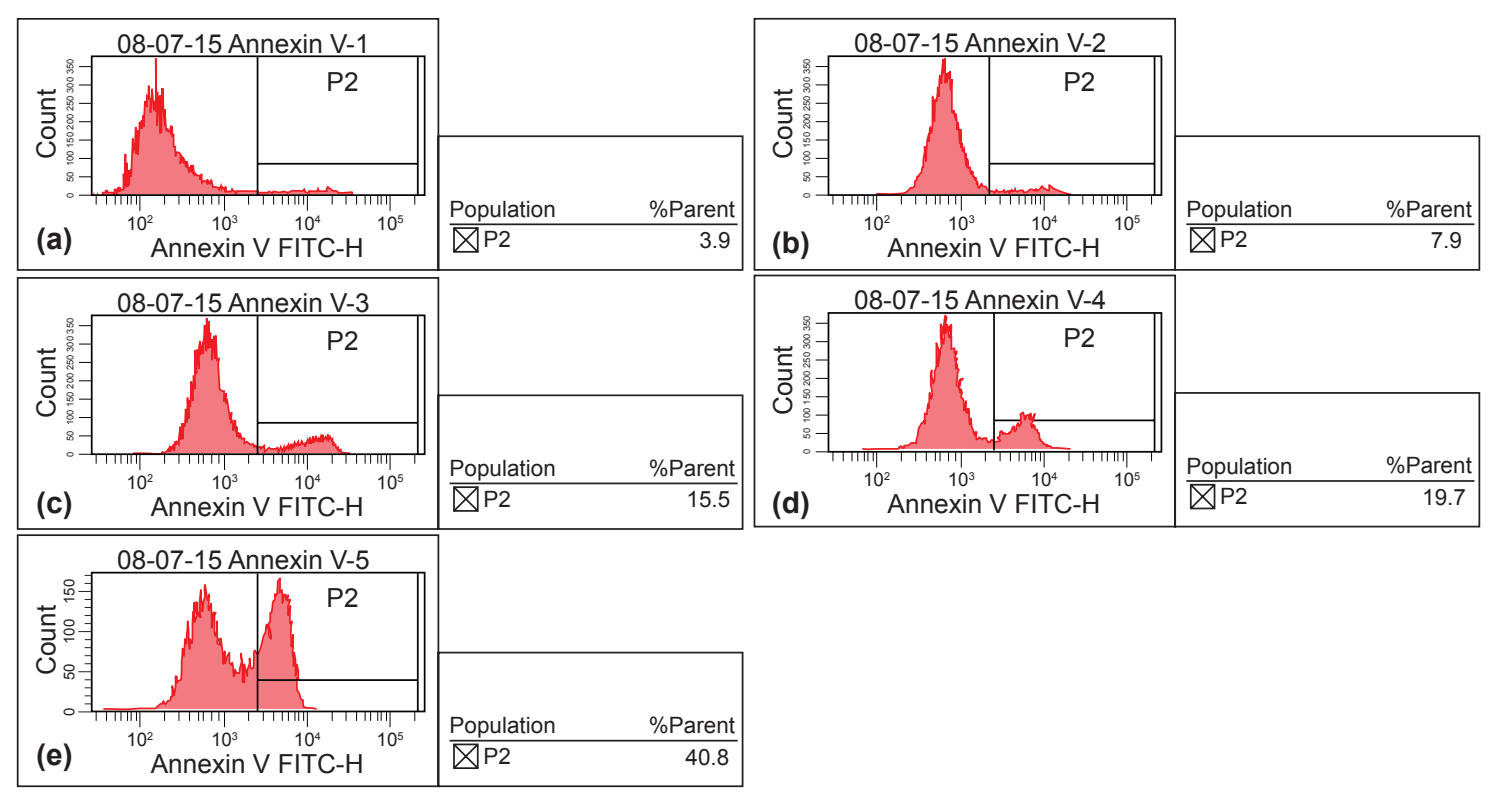

Figure I Effects of $\mathrm{MNP}\left(\mathrm{Fe}_{3} \mathrm{O}_{4}\right)$ and $\mathrm{BrTet}$ on DNR-induced apoptosis in $\mathrm{K} 562 / \mathrm{A0} 2$ cells for $48 \mathrm{~h}$. (a) control; (b) DNR I.0 $\mu \mathrm{g} / \mathrm{ml} ;$ (c) DNR I.0 $\mu$ g/ml + MNP(Fe $\left.\mathrm{O}_{4}\right) 50 \mu \mathrm{M}$; (d) DNR $1.0 \mu \mathrm{g} / \mathrm{ml}+\mathrm{BrTet} 0.5 \mu \mathrm{M}$; (e) DNR I.0 $\mu \mathrm{g} / \mathrm{ml}+\mathrm{MNP}\left(\mathrm{Fe}_{3} \mathrm{O}_{4}\right) 50 \mu \mathrm{M}+\mathrm{BrTet} 0.5 \mu \mathrm{M}$.

Abbreviations: BrTet, 5-bromotetrandrin; DNR, daunorubicin; $\mathrm{MNP}\left(\mathrm{Fe}_{3} \mathrm{O}_{4}\right)$, magnetic nanoparticle of $\mathrm{Fe}_{3} \mathrm{O}_{4}$. 


\section{DNA agarose gel electrophoresis demonstrated apoptosis}

After co-treatment of DNR $(1.0 \mu \mathrm{g} / \mathrm{ml})$ with $\mathrm{MNP}\left(\mathrm{Fe}_{3} \mathrm{O}_{4}\right)$ $(50 \mu \mathrm{M})$ and BrTet $(0.5 \mu \mathrm{M}), \mathrm{K} 562 / \mathrm{A} 02$ cells appeared on the DNA ladder; while a large dose of the chemotherapeutic agent, DNR $(20.0 \mu \mathrm{g} / \mathrm{ml})$, was incubated with K562/A02 cells for $48 \mathrm{~h}$, DNA agarose gel electrophoresis showed smear (Figure 2).

\section{Effects of $\mathrm{MNP}\left(\mathrm{Fe}_{3} \mathrm{O}_{4}\right)$ and/or BrTet on P53 mRNA and its protein}

The expression of p53 level was higher in K562/A02 cells than in the parental sensitive K562 cells $(\mathrm{p}<0.05)$, whereas $50 \mu \mathrm{M} \mathrm{MNP}\left(\mathrm{Fe}_{3} \mathrm{O}_{4}\right), 0.5 \mu \mathrm{M}$ BrTet or $1.0 \mu \mathrm{g} / \mathrm{ml}$ DNR did not influence its expression in K562/A02 cells $(\mathrm{p}>0.05)$ (Figures 3A, 3B). The level of $\mathrm{p} 53$ protein whose gene was upregulated by $\operatorname{MNP}\left(\mathrm{Fe}_{3} \mathrm{O}_{4}\right)$ or BrTet with DNR in K562/A02 cells also elevated $(\mathrm{p}<0.05)$. Furthermore, the results suggest that $\mathrm{MNP}\left(\mathrm{Fe}_{3} \mathrm{O}_{4}\right)$ and BrTet with DNR together increased the expression of p53 protein more effectively than $\mathrm{MNP}\left(\mathrm{Fe}_{3} \mathrm{O}_{4}\right)$ or BrTet with DNR alone $(\mathrm{p}<0.05)$.

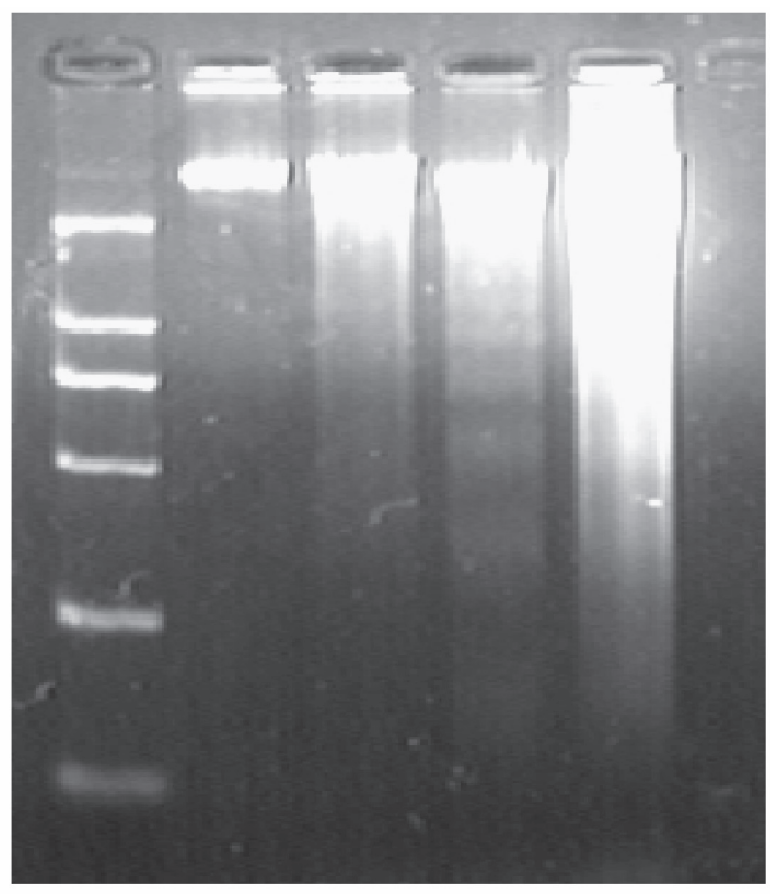

M

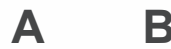

Figure 2 DNA agarose gel electrophoresis of K562/A02 incubated with different drugs for $48 \mathrm{~h}$.

Notes: M, Marker; A, control; B, DNR I.0 $\mu \mathrm{g} / \mathrm{ml}$; C, DNR I.0 $\mu \mathrm{g} / \mathrm{ml}+\mathrm{MNP}\left(\mathrm{Fe}_{3} \mathrm{O}_{4}\right)$ $50 \mu \mathrm{M}+\mathrm{BrTet} 0.5 \mu \mathrm{M}$; D, DNR $20.0 \mu \mathrm{g} / \mathrm{ml}$.

Abbreviations: $\mathrm{BrTet}$, 5-bromotetrandrin; $\mathrm{DNR}$, daunorubicin; $\mathrm{MNP}\left(\mathrm{Fe}_{3} \mathrm{O}_{4}\right)$, magnetic nanoparticle of $\mathrm{Fe}_{3} \mathrm{O}_{4}$.

\section{Effects of $\mathrm{MNP}\left(\mathrm{Fe}_{3} \mathrm{O}_{4}\right)$ and/or BrTet on caspase- 3 mRNA and its protein}

As shown in Figures 4A and 4B, caspase-3 was inhibited in Pgp-overexpressed cells after treatment with DNR. Nevertheless, when cells were treated with $\mathrm{MNP}\left(\mathrm{Fe}_{3} \mathrm{O}_{4}\right)$ or BrTet alone, the K562/A02 cells expressing caspase-3 showed significant resistance to these agents $(\mathrm{p}>0.05)$. However, the combination of DNR and $\mathrm{MNP}\left(\mathrm{Fe}_{3} \mathrm{O}_{4}\right)$ or BrTet yielded much more significant activation of caspase-3, and the expression of caspase-3 mRNA and protein were increased in response to application of $\mathrm{MNP}\left(\mathrm{Fe}_{3} \mathrm{O}_{4}\right)$ and BrTet with DNR together $(\mathrm{p}<0.05)$.

\section{Discussion}

Most cytotomic agents exert their anticancer effects by inducing apoptotic-programmed cell death. ${ }^{20}$ The resistance of leukemic cells to chemotherapy-induced apoptosis remains the most significant problem in the development of drug resistance and treatment failure in leukemia. ${ }^{3}$ Defects in the receptor- or mitochondrial-mediated apoptosis signaling pathway are implicated in the development of drug resistance and treatment failure in leukemia. ${ }^{21,22}$ In order to reverse the resistance mechanism, we chose the application of $\mathrm{MNP}\left(\mathrm{Fe}_{3} \mathrm{O}_{4}\right)$ and BrTet to enhance inducing leukemia cells apoptosis. $\mathrm{MNP}\left(\mathrm{Fe}_{3} \mathrm{O}_{4}\right)$ are widely used for targeted-drug carriers with target-orientation and sustained-release properties. ${ }^{9}$ In previous studies have demonstrated the synergistic effect of $\mathrm{MNP}\left(\mathrm{Fe}_{3} \mathrm{O}_{4}\right)$ with anticancer drug on the drug accumulation of leukemia K562 cells may help it to inhibit the relative drug resistance. ${ }^{10} \mathrm{We}$ previously reported that BrTet could effectively reverse P-gp-mediated $\mathrm{MDR},{ }^{16}$ and $\mathrm{MNP}\left(\mathrm{Fe}_{3} \mathrm{O}_{4}\right) \mathrm{s}$ loaded with chemotherapeutic agents and chemosensitizers have a synergetic effect on reveral in MDR. ${ }^{23}$

In order to investigate the cytotoxicity of $\mathrm{MNP}\left(\mathrm{Fe}_{3} \mathrm{O}_{4}\right)$ and BrTet on K562/A02 cells in vitro, we investigated the combined effects of DNR with either $\mathrm{MNP}\left(\mathrm{Fe}_{3} \mathrm{O}_{4}\right)$ or BrTet on the apoptosis of K562/A02 cell lines (Figure 1). The combination of DNR with either $\mathrm{MNP}\left(\mathrm{Fe}_{3} \mathrm{O}_{4}\right)$ or BrTet exerted a potent cytotoxic effect in K562/A02 cells, and co-treatment of $\mathrm{MNP}\left(\mathrm{Fe}_{3} \mathrm{O}_{4}\right)$ and $\mathrm{BrTet}$ had a distinct synergism on the enhancement of DNR-induced apoptosis in K562/A02 cells. This result showed that $\mathrm{MNP}\left(\mathrm{Fe}_{3} \mathrm{O}_{4}\right)$ or BrTet could enhance DNR-induced apoptosis in K562/A02 cells, and when used together, they have distinct synergism.

To check whether the effects of $\mathrm{MNP}\left(\mathrm{Fe}_{3} \mathrm{O}_{4}\right)$ and BrTet combining with a small dose chemotherapeutic agent was different from the effects of a large dose chemotherapeutic agent on K562/A02 cells, we detected the typical 
biochemistry feature of apoptotic by DNA gel electrophoresis. As shown in Figure 2, the typical apoptotic features appeared after co-treatment of DNR $(1.0 \mu \mathrm{g} / \mathrm{ml})$ with $\operatorname{MNP}\left(\mathrm{Fe}_{3} \mathrm{O}_{4}\right)$ and BrTet for $48 \mathrm{~h}$, while most cells showed necrosis after incubated with DNR $(20.0 \mu \mathrm{g} / \mathrm{ml})$ for $48 \mathrm{~h}$. This result showed that $\mathrm{MNP}\left(\mathrm{Fe}_{3} \mathrm{O}_{4}\right)$ or BrTet enhanced DNRinduced apoptosis in K562/A02 cells, while $20.0 \mu \mathrm{g} / \mathrm{ml}$ DNR led cells to necrosis, which supports our assumption that the effects of $\mathrm{MNP}\left(\mathrm{Fe}_{3} \mathrm{O}_{4}\right)$ and BrTet combining with a small dose chemotherapeutic agent was different from the effects of a large dose chemotherapeutic agent on K562/A02 cell. This suggests that a combination of $\mathrm{MNP}\left(\mathrm{Fe}_{3} \mathrm{O}_{4}\right)$ and BrTet could be a highly feasible candidate for the development of a new MDR modulator.

Apoptosis in response to most DNA-damaging agents usually requires p53 function, which engages primarily the intrinsic pathway. ${ }^{24}$ Tumors that have lost p53 function might help circumvent resistance to conventional therapies. $^{25}$ Therefore, further analysis of p53 status is required in cancer therapies. To explore the involvement of P53 in the resistance to antitumor agent-induced apoptosis, we determined the level of P53 by real-time PCR assay and Western blot. Our results revealed that p53 defects are linked to reduced chemosensitivity. Whereas $\mathrm{MNP}\left(\mathrm{Fe}_{3} \mathrm{O}_{4}\right)$, BrTet, or DNR did not change the expression of p53 mRNA in $\mathrm{K} 562 / \mathrm{A} 02$ cells, $\mathrm{MNP}\left(\mathrm{Fe}_{3} \mathrm{O}_{4}\right)$, and BrTet with DNR together increased the expression of $\mathrm{p} 53$ protein more effectively than $\mathrm{MNP}\left(\mathrm{Fe}_{3} \mathrm{O}_{4}\right)$ or BrTet with DNR alone (Figure 3). These results suggest that the augmention of P53 expression by DNR with $\mathrm{MNP}\left(\mathrm{Fe}_{3} \mathrm{O}_{4}\right)$ and BrTet possibly contributes to its apoptotic induction in this system. Since p53 defects are a major contributing factor in drug resistance and have been recently linked to reduced chemosensitivity, our results may have very important clinical implications. ${ }^{26}$

The initiation of a cascade of cysteine proteases of the ICE/ced3 family (caspases) plays a pivotal role in apoptosis. ${ }^{27}$ Caspase- 3 inhibition is essential for caspase activation in apoptosis. Our findings demonstrated that caspase-3 was the most likely caspase to mediate the composite-induced apoptosis, as shown in Figures 4A, 4B.

\section{Conclusion}

Our study demonstrates for the first time that $\mathrm{MNP}\left(\mathrm{Fe}_{3} \mathrm{O}_{4}\right)$ and BrTet at subcytotoxic doses significantly reversed MDR by synergistically enhancing DNR-induced apoptosis, and the distinct synergistic effect of that composite on reverse

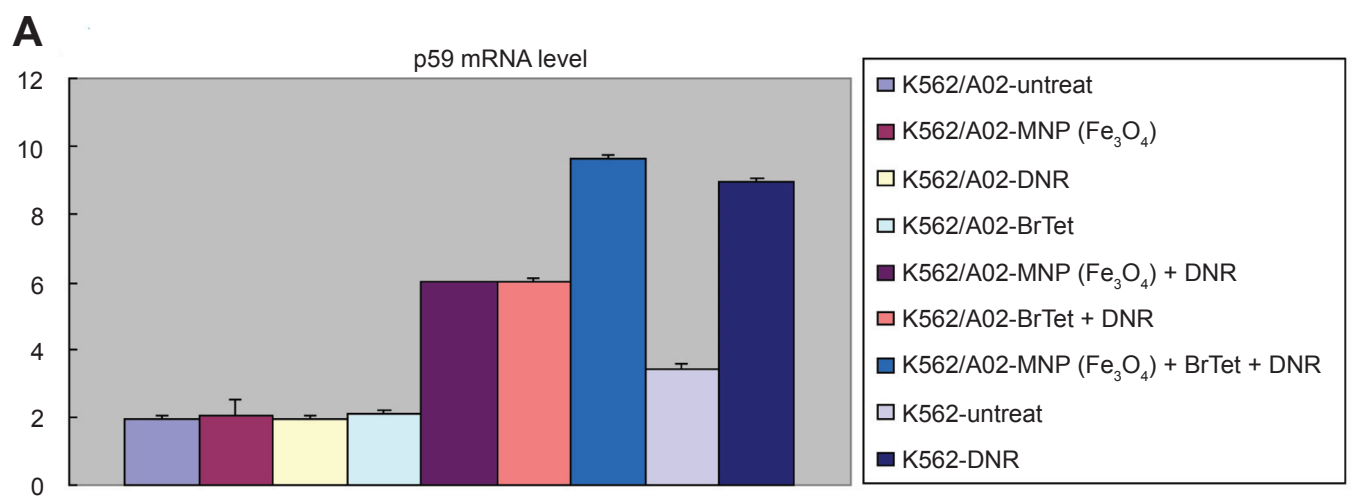

B

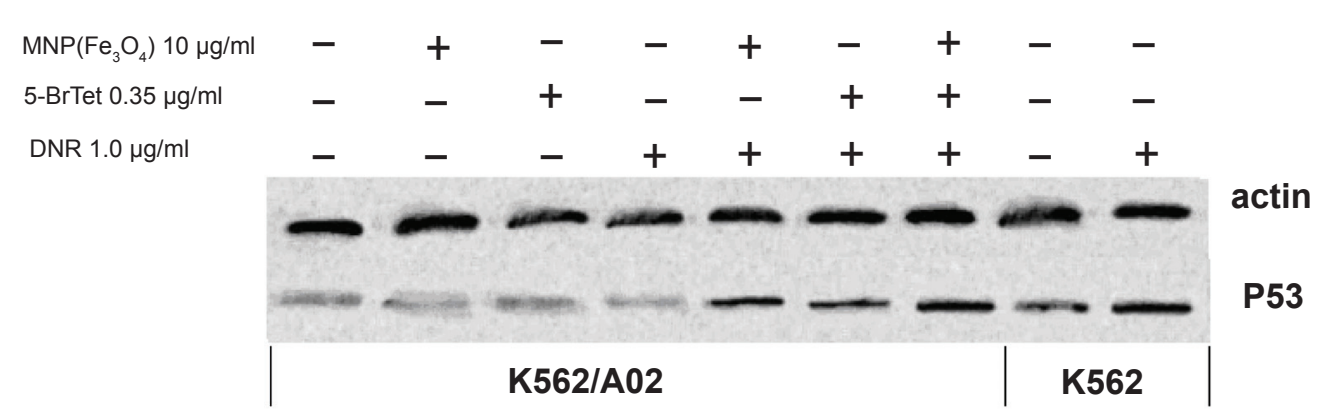

Figure 3 Effects of $\mathrm{MNP}\left(\mathrm{Fe}_{3} \mathrm{O}_{4}\right)$ and/or BrTet on P53 mRNA and its protein in K562 cells and K562/A02 cells. A) Real-time PCR analysis of P53 of K562 cells and K562/A02 cells after $48 \mathrm{~h}$ of treatment. B) Western blot analysis of P53 of K562 cells and K562/A02 cells after $48 \mathrm{~h}$ of treatment.

Abbreviations: $\mathrm{BrTet}$, 5-bromotetrandrin; $\mathrm{MNP}\left(\mathrm{Fe}_{3} \mathrm{O}_{4}\right)$, magnetic nanoparticle of $\mathrm{Fe}_{3} \mathrm{O}_{4} ; \mathrm{PCR}$, polymerase chain reaction. 

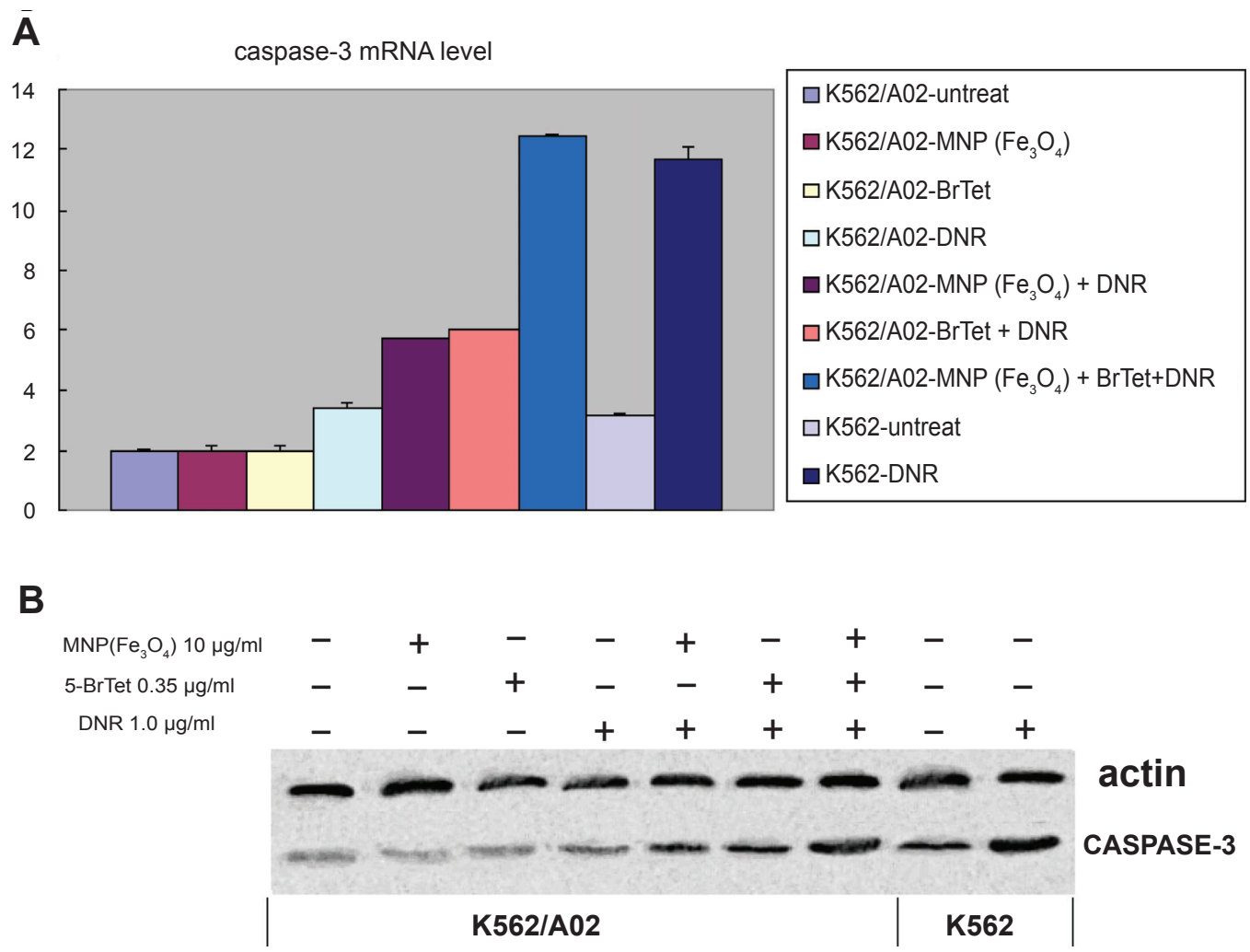

Figure 4 Effects of $\mathrm{MNP}\left(\mathrm{Fe}_{3} \mathrm{O}_{4}\right)$ and/or BrTet on caspase- 3 mRNA and its protein in $\mathrm{K} 562$ cells and $\mathrm{K} 562 / \mathrm{A} 02$ cells. A) Real-time PCR analysis of caspase-3 of K562 cells and K562/A02 cells after $48 \mathrm{~h}$ of treatment. B) Western blot analysis of caspase- 3 of K562 cells and K562/A02 cells after $48 \mathrm{~h}$ of treatment. Abbreviations: $\mathrm{BrTet}$, 5-bromotetrandrin; $\mathrm{MNP}\left(\mathrm{Fe}_{3} \mathrm{O}_{4}\right)$, magnetic nanoparticle of $\mathrm{Fe}_{3} \mathrm{O}_{4} ; \mathrm{PCR}$, polymerase chain reaction.

MDR may owe to the regulation of various proliferative and antiapoptotic gene products, including P53 and caspase-3. Thus, it may be possible that a combination of $\mathrm{MNP}\left(\mathrm{Fe}_{3} \mathrm{O}_{4}\right)$ and BrTet may be a more sufficient and less toxic anti-MDR method.

\section{Acknowledgments}

This work was supported by National 863 Program Emphasis Project: Nanometer Biology Ware Study (No.2007AA0222007), National Natural Science Foundation of P.R. China (No. 30740062 and No. 30872970) and High School Doctor Subject Special-purpose Scientific Research Foundation (No. 20070286042).

\section{References}

1. Ross DD. Novel mechanisms of drug resistance in leukemia. Leukemia. 2000;14:467-473.

2. List AF, Spier CS, Grogan TM, et al. Overexpression of the major vault transporter protein lungresistance protein predicts treatment outcome in acute myeloid leukemia. Blood. 1996;87:2464-2469.

3. Kataoka S, Naito M, Tomida A, et al. Tsuruo T. Resistance to antitumor agent-induced apoptosis in a mutant of human myeloid leukemia U937 cells. Exp Cell Res. 1994;215:199.

4. Gorczyca W, Gong J, Ardelt B, et al. The cell cycle related differences in susceptibility of HL-60 cells to apoptosis induced by various antitumor agents. Cancer Res. 1993;53:3186.
5. Page R, Tokimoto C. Cancer management: a multidisciplinary approach: medical,surgical,and radiation oncology. In: Pzadur R, editor. Principles of chemotherapy. 8th ed. New York, NY: PPR; 2004. p. 21-38.

6. Mikhail S. Nanobiotechnology today: focus on nanoparticles. J Nanobiotechnology. 2007;5:11.

7. Gilles KK, Joseph I. A nanoparticle-based immobilization assay for prion-kinetics study. J Nanobiotechnology. 2006;4:8.

8. Manuel A, Rodrigo FP, Ricardo I, et al. Magnetic nanoparticles for drug delivery. Nanotoday. 2007;2:3.

9. Lin BL, Shen XD, Cui S, et al. Application of nanosized $\mathrm{Fe}_{3} \mathrm{O}_{4}$ in anticancer drug carriers with target-orientation and sustained-release properties. Biomed Mater. 2007;2:132-134.

10. Zhang RY, Wang XM, Wu CH, et al. Synergistic enhancement effect of magnetic nanoparticles on anticancer drug accumulation in cancer cells. Nanotechnology. 2006;17:3622-3626.

11. Sun Q, Chen BA, Wang XM, et al. Preparation of $\mathrm{Fe}_{3} \mathrm{O}_{4}$-magnetic nanoparticles loaded with adriamycin and its reversal of multidrug resistance in vitro. J Exper Hematol. 2007;15:748-751.

12. Fu L, Liang Y, Deng L, et al. Characterization of tetrandrine, a potent inhibitor of P-glycoprotein-mediated multidrug resistance. Cancer Chemother Pharmacol. 2004;53:349-356.

13. Dai CL, Xiong HY, Tang LF, et al. Tetrandrine achieved plasma concentrations capable of reversing MDR in vitro and had no apparent effect on doxorubicin pharmacokinetics in mice. Cancer Chemother Pharmacol. 2007;60:741-750.

14. Xu WL, Shen HL, Ao ZF, et al. Combination of tetrandrine as a potential-reversing agent with daunorubicin, etoposide and cytarabine for the treatment of refractory and relapsed acute myelogenous leukemia. Leuk Res. 2006;30:407-413.

15. Jin J, Wang FP, Wei H, et al. Reversal of multidrug resistance of cancer through inhibition of P-glycoprotein by 5-bromotetrandrine. J Lipid Res. 2006;47:51-58. 
16. Wang JQ, Chen BA, Cheng J, et al. Comparison of reversal effects of 5-bromotetrandrine and tetrandrine on P-glycoprotein-dependent resistance to adriamycin in human leukemia cell line K562/A02. Ai Zheng. 2008;27:491-495.

17. Yan F, Jiang Y, Li YM, et al. Reversal of P-glycoprotein and multidrug resistance-associated protein 1 mediated multidrug resistance in cancer cells by HZ08 isomers, tetrataisohydroquinolin derivatives. Biol Pharm Bull. 2008;31:1258-1264.

18. Miao ZH, Jian D. Transcription factor c-Jun activation represses $m d r-1$ gene expression. Cancer Res. 2003;63:4527-4532.

19. Zhao YP, Chen G, Feng B, et al. Microarray analysis of gene expression profile of multidrug resistance in pancreatic cancer. Chinese Med J. 2007;120:1743-1752.

20. Reed JC. Regulation of apoptosis by bcl-2 family proteins and its role in cancer and chemoresistance. Curr Opin Oncol. 1995;7:541-546.

21. Schimmer AD, Hedley DW, Penn LZ, Minden MD. Receptor- and mitochondrial-mediated apoptosis in acute leukemia: a translational view. Blood. 2001;98:3541-3553.
22. Hannun YA. Apoptosis and the dilemma of cancer chemotherapy. Blood. 1997;89:1845-1853.

23. Chen BA, Sun Q, Wang XM, et al. Reveral in multidrug resistance by magnetic nanoparticle of $\mathrm{Fe}_{3} \mathrm{O}_{4}$ loaded with adriamycin and tetrandrine in $\mathrm{K} 562 / \mathrm{AO} 2$ leukemic cells. Int J Nanomedicine. 2008;3:277-286.

24. Kojima K, Konopleva M, Samudio IJ, et al. MDM2 antagonists induce p53-dependent apoptosis in AML: implications for leukemia therapy. Blood. 2005;106:3150-3159.

25. Hiroo H, Yasuaki Y, Kanki K, et al. Dihydroflavonol BB-1, an extract of natural plant Blumea balsamifera, abrogates TRAIL resistance in leukemia cells. Blood. 2006;107:679-688.

26. Lowe SW, Cepero E, Evan G, et al. Intrinsic tumour suppression. Nature. 2004;432:307-315.

27. Ibrado AM, Huang Y, Fang G, et al. Overexpression of Bcl-2 or Bcl-xL inhibits Ara-C-induced CPP32/Yama protease activity and apoptosis of human acute myelogenous leukemia HL-60 cells. Cancer Res. 1996;56:4743-4748 
